\title{
EFEKTIVITAS KEPADATAN BENIH LOBSTER AIR TAWAR (Cherax quadricarinatus) YANG BERBEDA TERHADAP PERTUMBUHAN DAN KELANGSUNGAN HIDUP PADA SISTEM RESIRKULASI
}

\section{THE EFFECTIVENESS IN DIFFERENT DENSITY OF FRESHWATER CRAYFISH SEED (Cherax quadricarinatus) ON GROWTH AND SURVIVAL RATE BY RECIRCULATION SYSTEM}

\author{
Ahmad Faiz $\left.{ }^{1 *}\right)$, Edward Danakusumah ${ }^{1)}$, Yudha Lestira Dhewantara \\ Fakultas Perikanan dan Ilmu Kelautan Universitas Satya Negara Indonesia \\ *Korespondensi : Sbmahmadfaiz@gmail.com
}

\begin{abstract}
ABSTRAK
Lobster air tawar merupakan salah satu jenis udang (crustacea) yang banyak digemari sehingga berpotensi untuk dikembangkan usaha. Salah satu spesies lobster air tawar yang termasuk dalam genus Cherax adalah Cherax quadricarinatus atau biasa dikenal dengan Red Claw (capit merah). Penggunaan sistem resirkulasi memerlukan biaya dan manajemen biosekuritas yang cukup tinggi, namun dapat menghasilkan produktivitas yang tinggi pula. Jika kondisi lingkungan optimal dan pakan yang diberikan cukup, maka padat penebaran dapat ditingkatkan sehingga dapat mencapai produksi yang maksimal. Penelitian ini bertujuan untuk meningkatan produktifitas pembesaran dengan berbagai padat penebaran melalui pemeliharaan benih didalam akuarium dengan penerapan pemeliharaan dengan sistem resirkulasi. Pembesaran lobster air tawar menghasilkan kelangsungan hidup tertinggi pada kepadatan 80 ekor/ $\mathrm{m}^{2}$ yaitu $100 \%$ Perlakuan pemeliharaan lobster dengan menggunakan sistem resirkulasi kepadatan 64 ekor $/ \mathrm{m}^{2} \quad(4$ ekor $)$ menghasilkan pertumbuhan bobot rata - rata sebesar 13,51 g, kepadatan 48 ekor $/ \mathrm{m}^{2}$ menghasilkan rata rata pertumbuhan panjang kerapak 6,87 g. Kepadatan 80 ekor/ $\mathrm{m}^{2}$ menghasil kan

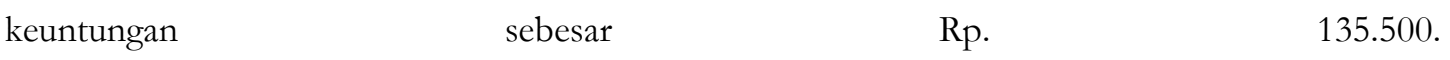
KATA KUNCI : lobster air tawar Cherax; resirkulasi; padat tebar; pertumbuhan. 


\begin{abstract}
Freshwater crayfish is one type of shrimp (crustacean) which is so popular that it has the potential to be developed for business. One species of freshwater crayfish that is included in the Cherax genus is Cherax quadricarinatus or commonly known as the Red Claw (red claws). The use of a recirculation system requires quite high costs and biosecurity management, but can also result in high productivity. If the environmental conditions are optimal and the feed is sufficient, the stocking density can be increased so as to achieve maximum production. This study aims to increase the productivity of enlargement with various stocking densities through the maintenance of seeds in the aquarium with the application of maintenance with a recirculation system. The enlargement of freshwater crayfish resulted in the highest survival at a density of 80 individuals $/ \mathrm{m}^{2}$, namely $100 \%$. The treatment of lobster rearing using a recirculation system with a density of 64 individuals $/ \mathrm{m}^{2}$ (4 individuals) resulted in an average weight growth of $13.51 \mathrm{~g}$, a density of 48 individuals $/ \mathrm{m}^{2}$. yielded an average growth of footprint length of $6.87 \mathrm{~g}$. A density of 80 individuals $/ \mathrm{m}^{2}$ results in a profit of Rp. 135,500 .
\end{abstract}

KEYWORD : freshwater crayfish, Cherax; recirculation; density; growth

\section{PENDAHULUAN}

Lobster air tawar merupakan salah satu jenis udang (crustacea) yang banyak digemari sehingga berpotensi untuk dikembangkan usaha budidayanya salah satu spesies lobster air tawar yang termasuk dalam genus Cherax adalah Cherax quadricarinatus atau biasa dikenal dengan Red Claw (capit merah) yang berasal dari benua Australia bagian Utara (Queensland dan Northern Territory) dan Papua New Guinea bagian Selatan (Munasinghe et al., 2004).Penggunaan sistem resirkulasi memerlukan biaya dan manajemen biosekuritas yang cukup tinggi, namun dapat menghasilkan produktivitas yang 
tinggi pula. Jika kondisi lingkungan optimal dan pakan yang diberikan cukup, maka padat penebaran dapat ditingkatkan sehingga dapat mencapai produksi yang maksimal. Penelitian ini bertujuan untuk meningkatan produktifitas pembesaran dengan berbagai padat penebaran melalui pemeliharaan benih didalam akuarium dengan penerapan pemeliharaan dengan sistem resirkulasi. Nilamsari (2007) memelihara lobster lewat pergantian air menunjukan bahwa peningkatan kepadatan dari 40 ekor/m² hingga $64 \mathrm{ekor} / \mathrm{m}^{2}$ diperoleh hasil terbaik pada kepadatan 40 ekor $/ \mathrm{m}^{2}$ dengan tingkat kelangsungan hidup 74,36\% hingga

85,71 .

\section{METODE PENELITIAN}

Hewan uji yang digunakan adalah benih Loster Air Tawar, perlakuan yang digunakan adalah kepadatan 48 ekor/m² (3 ekor), 64 ekor/ $\mathrm{m}^{2}$ (4 ekor), 80 ekor/ $\mathrm{m}^{2}$ (5 ekor),96 ekor/ m² (6 ekor)112 ekor/ m² (7 ekor), Alat-alat yang digunakan dalam penelitian ini adalah akuarium dengan ukuran 25 sebanyak 15 buah dengan kapasitas air 10 liter/akuarium, kamera digital, termometer, $\mathrm{pH}$ meter, DO meter, penggaris, timbangan digital, mesin pompa, selang sipon, peralon, dan alat tulis. Data yang diperoleh diuji sidik ragam (ANOVA). Apabila hasil yang diperoleh signifikan maka dilanjutkan dengan uji Tukey untuk mengetahui perbedaan antara perlakauan dengan menggunakan software SPSS versi 16. Selanjutnya data akan disajikan dalam bentuk tabel dan grafik.

\section{Prosedur penelitian}

Persiapan wadah pemeliharaan Pemeliharaan benih lobster air tawar dilakukan secara indoor dengan sistem resirkulasi menggunakan 15 wadah pemeliharaan berupa akuarium berukuran $25 \times 25 \times 30 \mathrm{~cm}$ dan 1 tandon yang juga berupa akuarium berukuran 100x40x45 cm. Benih lobster air tawar yang digunakan berumur 3 bulan, dengan bobot rata - rata sebesar $0.20 \pm 0.05 \mathrm{~g}$ dan panjang total rata-rata sebesar $5 \mathrm{~cm}$. Benih lobster air tawar berasal dari Bogor, Jawa Barat. Pemeliharaan benih lobster air tawar dilaksanakan selama 40 hari. Pakan diberikan sebanyak 5\% dari biomassa x $25 \times 30 \mathrm{~cm}$ 
lobster air tawar setiap hari. Pemberian pakan dilakukan 3 kali dalam sehari yaitu pada pukul 08.00, 13.00, dan 18.00 WIB.

\section{Rancangan percobaan}

Desain penelitian yang di gunakan adalah RAL (Rancangan Acak Lengkap) satu faktor yang terdiri dari 5 perlakuan dan masing- masing 3 kali ulangan

Perlakuan A : 3 ekor/Akuarium (48 ekor/m²)

Perlakuan B : 4 ekor/ Akuarium (64 ekor/ $\mathrm{m}^{2}$ )

Perlakuan C : 5 ekor/ Akuarium (80 ekor/ $\mathrm{m}^{2}$ )

Perlakuan D : 6 ekor/ Akuarium (96 ekor/ $\mathrm{m}^{2}$ )

Perlakuan E : 7 ekor/ Akuarium (112 ekor/ $\mathrm{m}^{2}$ )

Parameter Uji Tingkat Kelangsungan Hidup

Tingkat Kelangsungan Hidup (SR) dihitung untuk mengetahui persentase dari jumlah total benih lobster air tawar yang hidup hingga akhir masa pemeliharaan:

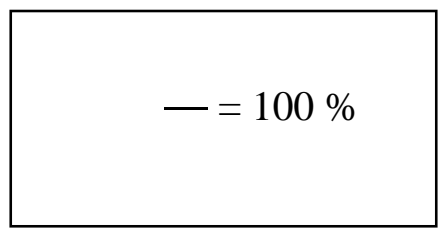

Keterangan:

SR : Tingkat kelangsungan hidup $(\%)$

Nt : Jumlah lobster air tawar hidup akhir pemeliharaan (ekor)

N0 : Jumlah lobster air tawar hidup awal pemeliharaan (ekor)

\section{Pertumbuhan Bobot}

Pertumbuhan bobot merupakan gambaran pertambahan bobot benih lobster air tawar selama pemeliharaan. Pertumbuhan bobot dihitung berdasarkan persamaan Effendie (1997).

$$
\mathrm{PB}=\mathrm{Bt}-\mathrm{B} 0
$$

Keterangan:

PB : Pertumbuhan bobot (g ekor-1)

Bt : Bobot rata-rata hari ke-t (g)

B0 : Bobot rata-rata awal penelitian

(g)

\section{Pertumbuhan Panjang Kerapak \\ Pertumbuhan panjang total merupakan gambaran pertambahan panjang total benih lobster air tawar yang diukur dari rostrum hingga telson selama pemeliharaan. Pertumbuhan panjang total dihitung berdasarkan persamaan Effendie (1997),}




$$
\mathrm{PP}=\mathrm{Pt}-\mathrm{P} 0
$$

\section{Keterangan:}

PP : Pertumbuhan panjang total

(g)

Pt : Panjang rata-rata hari ke-t (g)

P0 : Panjang rata-rata awal penelitian (g)

\section{Rasio Konversi Pakan (FCR)}

FCR adalah perbandingan antara jumlah pakan yang diberikan selama pemeliharaan dibagi dengan selisih bobot benih lobster air tawar pada waktu panen dan bobot benih lobster air tawar pada awal pemeliharaan. FCR dihitung berdasarkan persamaan Effendi (1997),

$$
\mathrm{RKP}=\frac{\mathrm{F}}{\mathrm{Bt}-\mathrm{B}_{0}}
$$

\section{Keterangan :}

FCR : Rasio konversi pakan

F :Jumlah pakan selama pemeliharaan $(\mathrm{g})$

Bt : Biomassa benih lobster air tawar pada akhir pemeliharaan (g)

Bo : Biomassa benih lobster air tawar mati selama pemeliharaan $(\mathrm{g})$

\section{Analisis Ekonomi}

Untuk menghitung pendapatan bersih usaha digunakan rumus menurut (Yunita, 2017).

$$
\pi=\mathrm{TR}-\mathrm{TC}
$$

Keterangan:

$\Pi$ : Pendapatan Bersih TR :

Pendapatan Kotor TC : Biaya Total

\section{HASIL DAN PEMBAHASAN}

a. Kelangsungan Hidup

Setelah masa pemeliharaan selama 40 hari, kelangsungan hidup lobster menurun seiring dengan bertambahnya waktu. Hasil penelitian menunjukan bahwa padat penebaran tidak berpengaruh terhadap tingkat kelangsungan hidup tersebut.

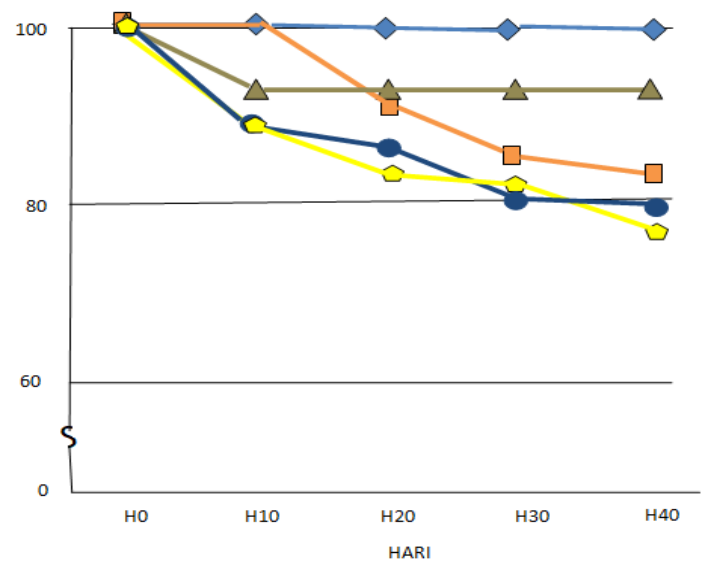

Gambar 4. Tingkat Kelangsungan Hidup (\%) 
Keterangan:

$$
\begin{aligned}
& : 3 \text { ekor/Akuarium }\left(48 \mathrm{ekor} / \mathrm{m}^{2}\right) \\
& : 4 \text { ekor/Akuarium }\left(64 \mathrm{ekor} / \mathrm{m}^{2}\right) \\
& : 5 \text { ekor/Akuarium }\left(80 \mathrm{ekor} / \mathrm{m}^{2}\right) \\
& : 6 \text { ekor/Akuarium }\left(96 \mathrm{ekor} / \mathrm{m}^{2}\right) \\
& : 7 \text { ekor/Akuarium }(112 \\
& \text { ekor/m } \left.{ }^{2}\right)
\end{aligned}
$$

Berdasarkan hasil uji (Tabel 4) menyatakan bahwa padat tebar yang berbeda dengan menggunakan sisitem resirkulasi tidak berbeda nyata. Hal ini diduga karena semakin tinggi padat tebar maka semakin rendah tingkat kelangsungan hidup nya

Hal ini diduga karena sifat agresif lobster yang berakibat kematian lebih tinggi pada kepadatan yang lebih tinggi peluang kematian juga meningkat akibat kondisi lemah ketika terjadi proses moulting. Pada saat itu lobster kehilangan unsur mineral terutama kalsium yang berkurang secara drastis dalam tubuhnya akibat lepasnya cankang keras dari tubuhnya. Pada proses pertumbuhan lobster dibutuhkan mineral kalsium yang dapat dicukupi dari makanan dan lingkungan (Hadie et al 2010). Sesuai dengan pendapat Wiyanto dan Hartono (2003) dalam
Ivan et al. (2013) saat proses moulting, lobster mengeluarkan bau tertentu yang mengundang lobster lainnya untuk mendekat dan memangsanya. Akibatnya, gangguan lobster lain yang menyebabkan kejutan pada lobster yang sedang mengalami moulting juga menyebabkan penyerangan meningkat dan dapat menyebabkan kematian bagi lobster tersebut bahkan dapat dimakannya (kanibal).

\section{b. Pertumbuhan Bobot}

Setelah masa pemeliharaan selama 40 hari, berat rata-rata lobster meningkat seiring dengan bertambahnya waktu, yakni dari 3.25 3.71 g menjadi $4.79 \quad-6.45 \mathrm{~g}$ (Lampiran 3 , Gambar 5 ). Banyak hal yang mempengaruhi pertumbuhan antara lain kualitas air makanan dan padat tebar. Lobster air tawar yang dipelihara selama penelitian mengalami pertumbuhan baik panjang maupun bobot. Pada akhir pengamatan berat rata-rata tertinggi dicapai pada perlakuan dengan padat penebaran 48 ekor/m² yakni sebesar, $4.99 \mathrm{~g}$, sedangkan berat rata-rata terendah dicapai pada perlakuan dengan penebaran 80 ekor $/ \mathrm{m}^{2}$ yakni sebesar 
3.94g dari hasil pengukuran pertumbuhan bobot mengalami peningkatan. Hasil penelitian padat tebar yang berbeda dengan menggunakan sistem resirkulasi berupa 48 ekor $/ \mathrm{m}^{2}, 64$ ekor $/ \mathrm{m}^{2}, 80$ ekor $/ \mathrm{m}^{2}, 96$ ekor $/ \mathrm{m}^{2}$ dan $112 \mathrm{ekor} / \mathrm{m}^{2}$ tidak berpengaruh nyata terhadap laju pertumbuhan bobot lobster air tawar red claw.

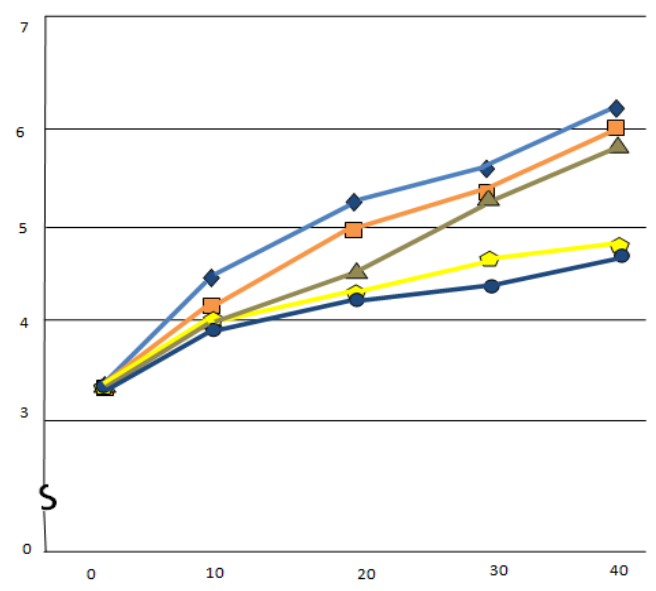

Gambar 5. Pertumbuhan Berat Lobster

Air Tawar Red Claw (Cherax quadricarinatus).

Keterangan:

$: 3 \mathrm{ekor} /$ Akuarium $\left(48 \mathrm{ekor} / \mathrm{m}^{2}\right)$
$: 4$ ekor/Akuarium $\left(64 \mathrm{ekor} / \mathrm{m}^{2}\right)$
$: 5$ ekor/Akuarium $\left(80 \mathrm{ekor} / \mathrm{m}^{2}\right)$
$: 6$ ekor/Akuarium $\left(96 \mathrm{ekor} / \mathrm{m}^{2}\right)$
$: 7$ ekor/Akuarium $\left(112 \mathrm{ekor} / \mathrm{m}^{2}\right)$
Dari grafik diatas dapat dilihat bahwa pemeliharaan lobster air tawar setiap minggu mengalami pertumbuhan yang baik pertumbuhan bobot harian selama pemeliharaan berkisar antara $0,02-\quad 0,14 \mathrm{~g}$. Berdasarkan hasil analisis ragam didapatkan peningkatan padat penebaran menghasilkan laju pertumbuhan bobot harian memberikan pengaruh yang tidak berbeda nyata ( $p>0,05)$. Hal ini diduga kemampuan lobster uji dalam mengkonsumsi pakan mampu dicerna dengan baik sehingga pertumbuhan optimum. Pada budidaya intensif, peningkatan kepadatan lobster akan diikuti dengan peningkatan kebutuhan oksigen dan makanan serta kotoran (metabolit dan sisa pakan). Sesuai dengan pendapat Hepher dan Pruginin (1981) selama oksigen dan pakan tersebut terpenuhi dan keberadaan metabolit dapat dikendalikan, ikan dapat tumbuh sesuai kapasitasnya (maksimal). Pertumbuhan bobot mutlak pada lobster air tawar red claw mengalami kenaikan selama penelitian. Hal ini menunjukan bahwa kandungan nutrisi pada pakan mampu dikonversi menjadi energi oleh lobster air tawar red claw. Sesuai dengan 
pendapat Widyati (2009) menyatakan bahwa jumlah protein akan mempengaruhi tingkat pertumbuhan ikan. Tinggi rendahnya protein dalam pakan dipengaruhi oleh kandungan Non-protein yaitu yang berasal dari karbohidrat dan lemak.

c. Pertumbuhan Panjang Kerapak

Setelah masa pemeliharaan selama 40 hari, panjang rata-rata lobster meningkat seiring dengan bertambahnya waktu, yakni dari 2.07 $2.39 \mathrm{~mm}$ menjadi $2.26-2.87 \mathrm{~mm}$. Pada akhir pengamatan panjang tertinggi dicapai pada perlakuan A dengan padat penebaran $\left(48 \mathrm{ekor} / \mathrm{m}^{2}\right)$ yakni sebesar, $2.87 \mathrm{~mm}$, sedangkan pajang terendah dicapai pada perlakuan E dengan penebaran (112 ekor/ $\mathrm{m}^{2}$ ) yakni sebesar $2.26 \mathrm{~mm}$. Semakin tinggi padat penebaran lobster air tawar maka semakin rendah petumbuhan nya sesuai dengan pendapat Hepher dan Pruginin (1981) pada ikan, peningkatan kepadatan akan diikuti dengan penurunan pertumbuhan jika jumlah pakan, oksigen terlarut, serta buangan metabolit tidak mampu dikendalikan.

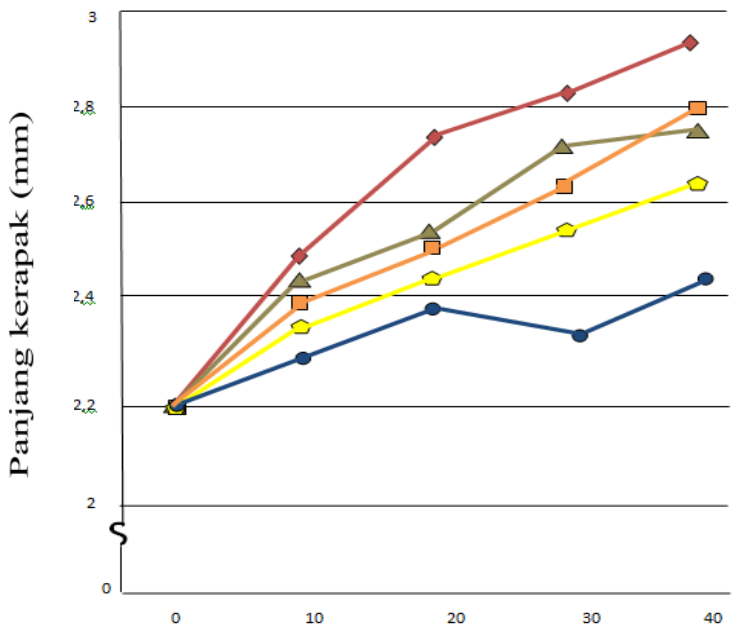

Gambar 6. Pertumbuhan Panjang Kerapak Rata - rata Lobster Air Tawar Red Claw (Cherax quadricarinatus).

Keterangan:

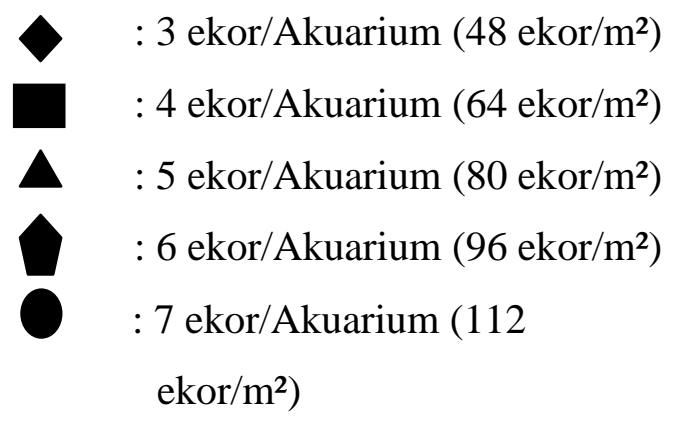

Hasil (Gambar 6) rata-rata laju pertumbuhan panjang bobot lobster air tawar red claw (Cherax quadricarinatus). Berdasarkan hasil penelitian padat tebar yang berbeda dengan menggunakan sistem resirkulasi berupa 48 ekor $/ \mathrm{m}^{2}, 64$ ekor $/ \mathrm{m}^{2}, 80 \mathrm{ekor} / \mathrm{m}^{2}, 96 \mathrm{ekor} / \mathrm{m}^{2}$ dan $112 \mathrm{ekor} / \mathrm{m}^{2}$ tidak berpengaruh nyata terhadap pertumbuhan panjang lobster air tawar red claw. Hal ini diduga 
karena lobster pada tiap perlakuan memiliki kemampuan dalam merespon dan memanfaatkan pakan untuk pertumbuhan. Selain padat tebar moulting juga memperngaruhi perumbuhan panjang kerapak sesuai dengan pendapat (Hadie et al. 2010). Pada fase pengerasan kulit diperlukan kalsium yang cukup tinggi sehingga kandungan kalsium yang terdapat di dalam hemolimf saja dinilai tidak mampu untuk menunjang proses molting. Hal ini dikarenakan hemolimf hanya dapat memenuhi kebutuhan kalsium sebesar $10 \%$ dari kebutuhan dan sisanya diperoleh dari dalam air. Sesuai dengan pernyataan Bunasir et al.(2002) yang menyatakan bahwa pertumbuhan ikan dipengaruhi oleh kemampuan dalam merespon dan memanfaatkan kuantitas pakan yang diberikan.

\section{d. Rasio Konversi Pakan (FCR) Jumlah rasio konversi paka ikan} uji dari hari pertama sampai hari ke-40 (empat puluh ) dapat dilihat pada (Lampiran 5 dan Tabel 5).

Tabel 5. Rasio Konversi Pakan lobster air tawar red claw (Cherax quadricarinatus).

\begin{tabular}{|c|c|c|c|c|}
\hline \multirow[t]{2}{*}{ NO } & Kepadatan & \multirow{2}{*}{$\begin{array}{c}\text { Konversi } \\
\text { Pakan }\end{array}$} & $\begin{array}{c}\text { Pertambahan } \\
\text { Berat }\end{array}$ & \multirow{2}{*}{$\begin{array}{c}\text { Tingkat } \\
\text { Kelangsungan } \\
\text { Hidup }(\%)\end{array}$} \\
\hline & $\left(\mathrm{ekor} / \mathrm{m}^{2}\right)$ & & (g/ekor/hari) & \\
\hline 1 & 48 & 3,30 & 3,49 & 88,80 \\
\hline 2 & 64 & 2,80 & 3,51 & 91,66 \\
\hline 3 & 80 & 4,27 & 2,42 & 100,00 \\
\hline 4 & 96 & 3,48 & 2,47 & 77,76 \\
\hline 5 & 112 & 3,07 & 3,18 & 76,16 \\
\hline
\end{tabular}

Hasil uji (Tabel 5) rata-rata rasio konversi pakan lobster air tawar red claw. Berdasarkan hasil penelitian padat tebar yang berbeda dengan menggunakan sistem resirkulasi berupa 48 ekor $/ \mathrm{m}^{2}, 64$ ekor $/ \mathrm{m}^{2}, 80$ ekor/m², 96 ekor/m² dan 112 ekor/m² tidak memberikan pengaruh yang tidak berbeda nyata terhadap lobster air tawar red claw. Hal ini diduga bahwa pakan yang diberikan sedikit terhadap konsumsi pada lobster tetapi lobster dapat memanfaatkan pakan yang di berikan secara optimum sehingga pakan tersebut diserap dan di ubah menjadi daging kandungan nutrisi pakan dalam setiap perlakuan telah mencukupi selain pakan yang mempengaruhi FCR adalah perlakuan yang tidak jauh berbeda. Sesuai dengan pendapat Barrows dan Hady (2001), nilai rasio konversi pakan di pengaruhi oleh beberapa faktor seperti kepadatan, berat setiap individu, umur 
kelompok hewan, suhu air dan cara pemberian pakan (kualitas, jumlah dan frekuensi pemberian pakan). Besar kecilnya FCR diduga karena penyerapan nutrisi yang berbeda-beda pada setiap spesies, umur dan jumlah lobster uji. Sesuai dengan pendapat Pramudiyas (2014) salah satu faktor yang mempengaruhi nilai konversi pakan tinggi yaitu kualitas pakan yang kurang baik. Kualitas pakan dipengaruhi oleh daya cerna ikan terhadap pakan.

\section{e. Kualitas Air}

a) Suhu

Berdasarka hasil penelitian menyatakan bahwa pertumbuhan pada benih lobster air tawar selama penelitian mengalami kenaikan dan suhu dalam batas normal dari pernyataan di atas terlihat bahwa suhu terendah adalah $27,0^{\circ} \mathrm{C}$ dan tertinggi adalah $29,8^{0} \mathrm{C}$ keseluruhan masih dalam kisaran yang dapat ditolerir oleh lobster untuk hidup maupun tumbuh. Suhu selama pemeliharaan relatif optimum bagi pertumbuhan lobster, semakin tinggi suhu maka kandungan oksigen terlarut semakin rendah, demikian pula sebaliknya. Oksigen dalam suatu perairan tidak lepas dari pengaruh parameter lain seperti karbondioksida, alkalinitas, suhu, $\mathrm{pH}$, dan sebagainya. Dimana semakin tinggi kadar oksigen yang dibutuhkan, maka karbondioksida yang dilepaskan sedikit. Sesuai dengan pernyataan (Efendi, 2003). Hubungan antara kadar oksigen terlarut dengan suhu ditunjukkan bahwa semakin tinggi suhu, kelarutan oksigen semakin berkurang. Suhu selama penelitian, masih dalam kisaran yang baik untuk pertumbuhan Lobster air tawar. Kisaran tersebut baik untuk pertumbuhan lobster seperti yang dinyatakan Holdich dan Lowery (1988). Lobster air tawar dapat hidup pada selang parameter air yang lebar, lobster air tawar tolearn terhadap kandungan oksigen terlarut sangat rendah akan tetapi untuk tumbuh dan berkembang dengan baik tentu tidak akan dapat dilakukan pada kondisi demikian. Lobster jenis red claw akan mengalami pertumbuhan terbaik pada suhu 24- $29^{\circ} \mathrm{C}$

b) $\mathrm{pH}$

Selama pemeliharaan 40 hari didapatkan nilai $\mathrm{pH}$ untuk 
pertumbuhan lobster terendah 7.0 dan tertinggi adalah 8.5. Hal ini tidak jauh berbeda dengan pernyataan Holdich dan Lowery (1988) bahwa pertumbuhan Cherax quadricarinatus adalah berkisar 6.5-9. Lobster air tawar hidup pada perairan $\mathrm{pH}$ sedikit alkalin yaitu 7-9 dan jarang dijumpai di perairan dengan $\mathrm{pH}$ kurang dari 7 tingkat kelangsungan hidup tertinggi populasi lobster air tawar antara 7-8. Nilai $\mathrm{pH}$ yang kurang dari 5 sangat buruk bagi kehidupan udang karena dapat menyebabkan kematian, sedangkan $\mathrm{pH}$ diatas 9 dapat menurunkan nafsu makan. Perairan yang lebih asam dari pH 6,5 atau lebih basa dari pada $\mathrm{pH}$ 9-9,5 dalam jang kawaktu yang lama, reproduksi dan pertumbuhan akan menurun dan akan memiliki pertumbuhan yang baik pada pH 6,5-9. Selain itu juga, tinggi rendahnya $\mathrm{pH}$ dalam suatu perairan dapat dipengaruhi oleh jumlah kotoran dalam lingkungan perairan, khususnya sisa pakan dan hasil metabolisme. Sesuai dengan pendapat Mosigh (1998) lobster air tawar dapat hidup pada kisaran pH 6-9 dan memiliki kisaran optimum pada $\mathrm{pH}$ 7-8. Sesui dengan pendapat (Hastuti et al 2016). Nilai $\mathrm{pH}$ dapat berpengaruh terhadap pertumbuhan melalui kemampuan proses fisiologis, biokimiawi, struktur insang.
a) $\mathrm{DO}$

Kandungan oksigen terlarut selama penelitian ini cukup baik untuk pertumbuhan cherax yaitu terendah adalah 3,0 mg/l dan tertinggi adalah $6 \mathrm{mg} / \mathrm{l}$ atau rata rata $4,3 \mathrm{mg} / \mathrm{l}$. Kandungan oksigen terlarut selama penelitian dari awal pemeliharaan sampai akhir pemeliharaan mengalami penurunan. Peningkatan aktivitas berarti peningkatan kebutuhan oksigen, yang melibatkan respon sistem pernafasan dan sistem peredaran darah untuk meningkatkan ketersediaan oksigen. Sesuai dengan pendapat Boyd (1982) kisaran nilai optimum oksigen terlarut bagi pertumbuhan krustasea adalah di atas 5 mg/l, meskipun demikian kandungan oksigen terlarut 4,21-5,43 mg/l masih dapat memberikan pertumbuhan dan kelangsungan hidup yang baik. Sesuai dengan pendapat Mosigh (1998) lobster air tawar dapat mentoleransi 
kandungan oksigen terlarut di air hingga $1 \mathrm{mg} / \mathrm{l}$.

Sementara itu penurunan jumlah oksigen, tersebut diakibatkan banyaknya bahan organik berupa sisa pakan maupun kotoran yang berada didalam wadah pemeliharaan. Penurunan oksigen dalam air tergantung pada banyaknya partikel organik dalam air yang membutuhkan perombakan oleh bakteri melalui proses oksidasi. Sesuai dengan pendapat (Lesmana, 2005) makin banyak partikel organik, maka makin banyak aktivitas bakteri perombak dan makin banyak oksigen yang dikonsumsi sehingga makin berkurang oksigen dalam air. Sesuai dengan pendapat Anonimus SDF(2006), yang menyatakan bahwa konsentrasi oksigen terlarut yang baik untuk mendukung pertumbuhan lobster adalah lebih dari $5 \mathrm{mg} / \mathrm{l}$.

\section{f. Analisis Ekonomi}

Berdasarkan hasil penelitian benih lobster air tawar hubungan antara padat tebar, kelangsungan hidup, dan nilai ekonomi pada penelitian ini.
Analisis ekonomi disediakan dalam sebagai berikut :

Tabel 7. Nilai Ekonomi

\begin{tabular}{|c|c|c|c|c|c|c|c|c|c|}
\hline \multicolumn{10}{|c|}{ Andis'sis Etonomi } \\
\hline \multirow{2}{*}{ Perlakuan } & Jumlan lovster & Kelangungenan & jumlan lonser & Paniangleonster & Hapgo & Pendadodian & Hageberin & Harge & \\
\hline & (elor) & 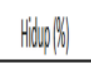 & Hidupdidkiri & dibkir & Rplethor| & $|R|$ & $|R| l|g|$ & Palken & Keutungen R. R \\
\hline Helor/m" & 3elor)/Aurainm & 889 & 8 & Sinci & 20,000 & 160,000 & 2500 & 22.000 & 115.500 \\
\hline Geleor/m? & Selor)/Auarimm & 91.66 & 11 & Sinci & 20,000 & 220,000 & 2500 & 22,000 & 168,000 \\
\hline Detor/m' & Selor/Aubrim & 100 & 15 & Gima & 15,000 & 375.000 & 2500 & 22000 & 315500 \\
\hline ghethor/m' & Gecor/Alubrium & 77,6 & 14 & Ainoi & 10,000 & 140,000 & 2500 & 22,000 & 73.000 \\
\hline 1112 elor/m? & Teloro/ Aluarim & 76,16 & 16 & 4inci & 10,000 & 100,000 & 2500 & 22,000 & .72000 \\
\hline
\end{tabular}

Berdasarkan hasil analisis ekonomi diatas hasil ekonomi pada kepadatan 3 ekor/akurium. Dengan kelangsungan hidup $88 \%$ dengan jumlah lobster akhir sebanyak 8 ekor jika dikalikan dengan harga jual $\mathrm{Rp}$ 20.000 lalu dikurangi dengan biaya pakan sebesar Rp 22.000 ditambah dengan biaya benih sebesar Rp 22.500 mendapatkan hasil sebesar Rp 115.500 kemudian pada kepadatan 4 ekor/akuarium. Dengan kelangsungan hidup $91 \%$ dengan jumlah ikan akhir sebanyak 11 ekor jika dikalikan dengan harga jual Rp 20.000 lalu dikurangi dengan biaya pakan sebesar Rp 22.000 dan ditambah biaya benih sebesar Rp 30.000 maka didapatkan 
hasil sebesar Rp 168.000. Pada kepadatan 5 ekor/akuarium dengan tingkat kelangsungan hidup sebesar $100 \%$ dengan jumlah ikan akhir sebanyak 15 ekor jika dikalikan dengan harga jual Rp 25.000 lalu dikurangi dengan biaya pakan sebesar Rp 22.000 dan ditambah biaya benih Rp 37.500 akan mendapatkan hasil sebesar Rp 315.500. Pada kepadatan 6 ekor/akuarium dengan tingkat kelangsungan hidup sebesar 77\% dengan jumlah ikan akhir sebanyak 14 ekor jika dikalikan dengan harga jual Rp 10.000 lalu dikurangi dengan biaya pakan sebesar Rp 22.000 dan ditambah biaya benih $\mathrm{Rp} 45.000$ akan mendapatkan hasil sebesar Rp 73.000. Lalu pada kepadatan 7 ekor/akuarium dengan tingkat kelangsungan hidup sebesar $76 \%$ dengan jumlah ikan akhir sebanyak 16 ekor jika dikalikan dengan harga jual Rp 10.000 lalu dikurangi dengan biaya pakan sebesar Rp 22.000 dan ditambah biaya benih Rp 52.500 akan mendapatkan hasil sebesar Rp -72.000 Maka dapat disimpulkan dengan tingkat kelangsungan hidup tinggi dapat mempengaruhi tingginghasilan yang

\section{KESIMPULAN}

Pembesaran lobster air tawar menghasilkan kelangsungan hidup tertinggi pada kepadatan 80 ekor/ $\mathrm{m}^{2}$ yaitu $100 \%$ Perlakuan pemeliharaan lobster dengan menggunakan sistem resirkulasi kepadatan 64 ekor/m² (4 ekor) menghasilkan pertumbuhan bobot rata - rata sebesar 13,51 g, kepadatan 48 ekor/m² menghasilkan rata - rata pertumbuhan panjang kerapak 6,87 g. Kepadatan 80 ekor/ m² menghasil kan keuntungan sebesar Rp. 135.500 .

\section{SARAN}

Berdasarkan hasil penelitian ini untuk skala produksi budidaya lobster air tawar di pendederan disarankan menggunakan kepadatan 80 ekor $/ \mathrm{m}^{2}$.Pada penelitian berikutnya disarankan agar diteliti model wadah budidaya yang cocok dengan sistem resirkulasi memanfaatkan ruang, serta kepadatan optimal setiap perlakuannya pada wadah budidaya. 


\section{DAFTAR PUSTAKA}

Anonimus. 2006. Biologi Lobster Air Tawar (Freshwater Crayfish). http:www.ofish.com/LobsterAirTawar(Fresh waterCrayfish)/Biologi.html.[22 November 2006].

Barrow, P. A. dan Hardy. 2001 Probiotic for Chickens. In: Probiotics the Scientrific Basis. R. Filter (Ed). London: Chapman and Hall.

Boyd, C.E. 1982. Pengelolaan Kualitas Air dalam budidaya Perikanan. Alih Bahasa: A.S. Sidik. 2001. Fakultas Perikanan dan Ilmu kelautan. Universitas Mulawarman. Samarinda.

Bunasir, M.N., Fahmi, G.T. dan Fauzan, M. 2002. Pembesaran Ikan Papuyu (Anabastestudineus Bloch) yang Dipelihara dalam Kolam Sebagai Salah Satu Alternatif Usaha.[Laporan Perekayasaan]. Lokakarya budidaya Air Tawar Kalimantan Selatan.Direktorat Jendral Perikanan budidaya. Depertemen Kelautan dan Perikanan. Banjarbaru.

Effendie, M. I. 1997. Biologi Perikanan.Yayasan Pustaka Nusantara. Yogyakarta.

Hadie, dan Kusmini. 2010. Kajian Efektivitas Kalsium untuk Pengembangan Teknologi Intensif pada Budidaya Lobster Air Tawar (Cherax quadricarinatus). Pusat Riset Perikanan Budidaya. Jurnal Akuakultur Indonesia hal.: 221 -228 .
Hastuti S, Supriyono E, Mokoginta I, Subandiyuno. 2003. Respon glukosa darah ikan gurami (Osphronemus gouramy, LAC) terhadap stres perubahan suhu lingkungan. Jutnal Akuakultur Indonesia. 2:73-77.

Hepher, B. and Pruginin, Y. 1981. Commercial Fish Farming With Special Reference to Fish Culture in Israel. John Willey and Sons, Inc. New York.

Holdich, D.M. and Lowery, R.S. 1988. Freshwater Cryfish: Biology Management and Exploitation. Croom Helms, London and Sydney And Timber Press, Portland Oregon.

Ivan, R., Sadikin, A. dan Zaenal. A. 2013. Pertumbuhan Lobster Air Tawar (Cheraxquadricarinatus) padaPemberian Pakan dengan Frekuensi yang Berbeda.

Lesmana, D.S. 2005. Kualitas Air untuk Ikan Hias Air Tawar. Penebar Swadaya. Jakarta.

Mosigh, J. 1998. The Australian Yabby Farmer. 2th edition. Austalia: Lanklink Press.

Munasinghe, D., Burridge, C., dan Austin,C.C. 2004. Molecular phylogeny and zoogeography of the freshwater crayfish genus Cherax Erichson (Decapoda: Parastacidae) in Australia. Biol J Linn Soc. 81(81): 553-563.

Nilamsari. 2007. Pengaruh Perbedaan Padat Penebaran Terhadap Pertumbuhan dan Kelangsungan Hidup Lobster 


\begin{abstract}
Air Tawar Cherax quadricarinatus. [Skripsi]. BDP. FPIK. IPB. Bogor.
\end{abstract}

Pramudiyas, D.R. 2014.Pengaruh Pemberian Enzim pada Pakan Komersil terhadap Pertumbuhan dan Rasio Konversi Pakan (FCR) pada Ikan Patin (Pangasius sp.) [Skripsi] Universitas Airlangga. Surabaya. 64 hlm.

Yunita, I. 2017. Analisis Kelayakan Usaha Dodol Pulut di Desa Puloh Kecamatan Peusangan Kabupaten Bireuen. Jurnal S. Pertanian 1 (10) : 826- 836. 